\title{
Current and Future Issues Confronting Florida Turfgrass Producers
}

\author{
John J. Haydu and John L. Cisar \\ University of Florida, Institute of Food and Agricultural Sciences, Ft. Lauderdale Research and Education \\ Center, 3205 College-Avenue, Fort Lauderdale, FL 33314
}

The turfgrass industry contributes substantially to the economy of Florida. In 1974, a survey showed that grass maintained on all user classes of property covered 370,000 ha (Florida Dept. of Agriculture and Consumer Services, 1976). In that calendar year, $\$ 450$ million was spent for turf maintenance. This sum represented $24 \%$ of Florida farm receipts for all agricultural commodities. Today, if one accounts for a near doubling in the state's population and adjusts to current dollars, maintenance expenditures would likely reach several billion dollars.

The turfgrass sod industry consists of at least five distinct economic stages: a) input suppliers; b) turfgrass (sod) producers; c) distributors; d) wholesale/retail firms, brokers, and landscape contractors, and e) landscape maintenance. This industry can be conceptualized as pyramid-shaped (with input suppliers at the top and the maintenance sector at the bottom), where the number of firms and economic value of the industry increases significantly with each succeeding economic stage.

As suppliers of the grasses purchased by various user groups, sod growers play a major role in this industry. First, in terms of product, consumers depend on them for an adequate and reliable supply. of quality grasses. Few alternatives are readily available because of the commodity's extreme perishability once harvested and the prohibitive costs of- shipping sod over long distances. A related factor involves the legal restrictions limiting interstate shipping of certain grasses for fear of concurrent importation of harmful organisms. Public- or private-sector researchers who import new cultivars must first submit the cultivar to an extensive screening process to guard against St. Augustinegrass decline virus (Florida Dept. of Agriculture and Consumer Services, 1981). Second, in terms of economic impact, the quantity and value of turfgrass sales have roughly doubled since the 1974 survey, from 9500 ha at $\$ 46$ million (inflation-adjusted dollars) to 14,405 ha at $\$ 103$ million [estimates obtained and amended from

Received for publication 17 Nov. 1989. Florida AgriculturalExperimentStation Journal Series no. R-00271. The cost of publishing this paper was defrayed in part by the, payment of page charges. Underpostal regulations, this paper therefore must be hereby marked advertisement solely to indicate this fact.
Florida Dept. of Agriculture and Consumer Services (1976) and from data in the 1987 sod survey (Cisar et al., 1988)]. In spite of its significance as a major activity in the Florida economy, little economic information is available on the turfgrass industry.

Turfgrass producers are currently faced with a growing number of production and marketrelated problems. An absence of current information limits the effectiveness of decisions at both the corporate and, more recently, the industry level. In 1987, an extensive survey was conducted to ameliorate this situation, focusing on sod production, agronomic and cultural practices, marketing, and perceptions of industry problems (Cisar et al., 1988). Earlier information was limited to an extensive 1968 study by Smith and Brewster (1968) and less coverage in the 1974 Florida Turfgrass Survey (Florida Dept. of Agriculture and Consumer Services, 1976).

Our report discusses major concerns of sod growers, based on survey findings, and highlights issues that are influencing them to alter their independent behavior in favor of more cooperative approaches to solving industry-wide problems.

The sample for the 1987 Florida sod survey (Cisar et al., 1988) was constructed from the membership list of Turfgrass Producers of Florida (TPAF). A total of 119 questionnaires were mailed and 73 were returned, providing a $62 \%$ response rate. However, 24 of the 73 survey instruments were incomplete, as the respondents were either vendors, consultants, or former producers. These were eliminated from the sample, as were three additional respondents who were producers of potted plugs and not representative of the cut sod industry.

Turfgrass producers fell into two categories: 1) regular growers who harvested their sod annually and 2) growers who harvested on a periodic basis. The latter group were limited to bahiagrass (Paspalum notatum Fluegge) production and, as a rule, entered the market only when the economic returns exceeded those from alternative sources, usually livestock production. Consequently, we believe that the sample of growers surveyed constituted the majority of sod production in Florida.

Respondents were asked to rate the importance of seven problem areas $(5=$ very important, 3 = somewhat important, and 1 $=$ not important) as they affect turfgrass production. Specifically, these issues were: 1) water management-supply and demand, 2) government regulation, 3) production efficiency, 4) release of improved grass cultivars, 5) soil subsidence and removal, 6) nutrient and pesticide runnoff, and 7) marketing. Grower ranking of these issues are shown in Fig. 1.
NUMBER GROWERS PER CATEGORY

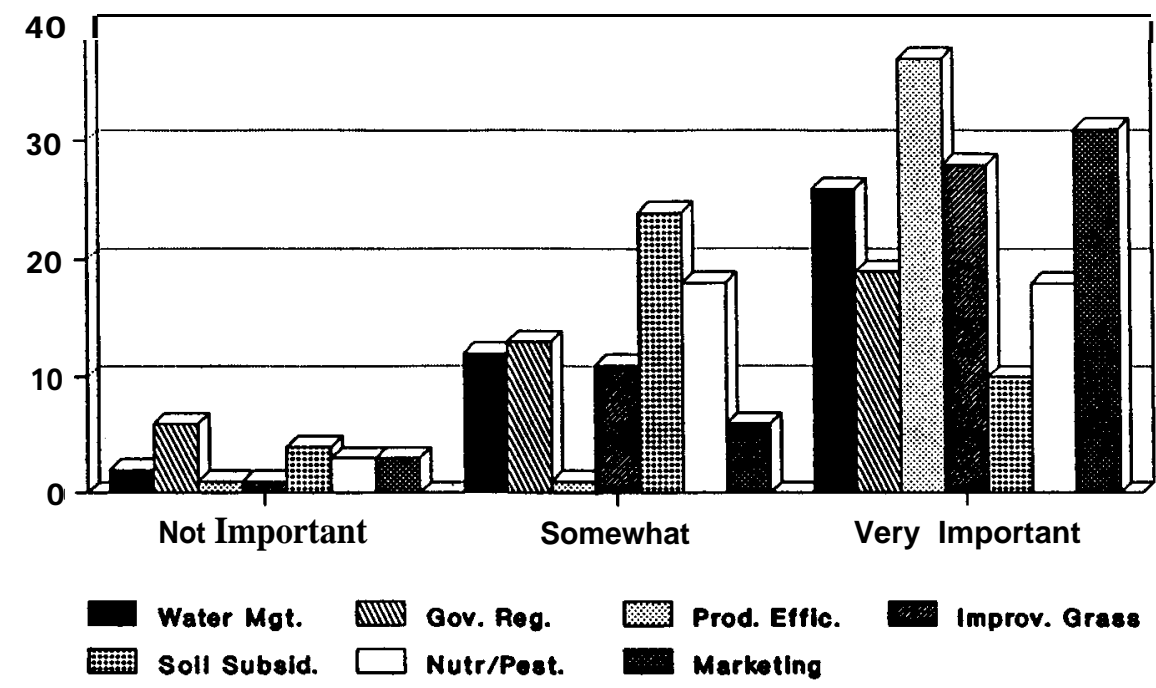

Fig. 1. Ranking of issues important to Florida turfgrass producers in 1987. 
Turfgrass producers were generally concerned with most issues. In category 5 , production efficiency and marketing received the highest rankings, while soil subsidence, nutrient and pesticide runoff, and government regulation were viewed as the least important. Assuming sod producers are accurate in their assertions of increasing competition, inadequate prices, and declining profit margins, the greater concern for production efficiency and marketing is not surprising. This would also explain their desire to obtain improved grasses that can be used as marketing tools by promoting them as new and better products.

A useful analysis is to evaluate grower perceptions by their relative economic position in the industry. Depending on the nature of the industry problem, one might expect small sod operations to be affected differently than very large ones. For instance, this disparity could stem from an "economies of size" advantage that large-scale growers may have over their smaller counterparts. However, when applied to production efficiency and improved grasses, no substantial differences were present across farm size, ranging from small $(<200$ ha) to very large $(>800$ ha).

Marketing as an industry concern did vary across farm size categories. A significant negative correlation was found between a sod operation's size. and the degree of concern for marketing; producers from large sod farms were more ambivalent about marketing issues than were small-farm operators. Using a Fisher's exact test (useful when conditions for a chi-square test are not met), this relationship was statistically significant at $P=$ 0.05 . This result may lend credence to one or more of the following hypotheses: 1) over time, large-farm operators have developed reliable and efficient exchange arrangements with first-handlers, thereby eliminating the need for market-related programs; 2) through economies of size, large-farm operators are able to produce and sell sod cheaper than their smaller competitors, in effect eliminating much of the competition; 3) large-farm operators have sufficient capital resources to implement effective marketing programs on their own.

Although grower apprehension over government regulation and nutrient and pesticide runoff was largely overshadowed by more immediate economic concerns, evidence suggests this may be changing. First, the Immigration Control Act of 1986 allows alien workers the right to become U.S. citizens. A reasonable presumption is that many of these new citizens, who were previously employed in agriculture, will seek alternative employment opportunities that are less physically demanding and more economically rewarding. Second, the new minimum wage legislation will raise hourly wages from $\$ 3.35$ to $\$ 4.25$. This law has obvious pecuniary repercussions for the turfgrass sod industry, especially for producers located in southern Florida. In contrast to the more mechanized turfgrass industry in northern Florida, this group uses substantial amounts of labor for hand-stacking sod onto pallets once it has been cut.

The continued pace of urban growth coupled with popular environmental concerns for clean and ample water supplies also signifies an increased likelihood of restrictive legislation on the turfgrass industry. As more costeffective pesticides are removed from the marketplace, producer efforts to maintain turf quality become more difficult and expensive. Excessive use, or even availability, of water may become a more contentious issue in the future as urban populations increase. To underscore this point, the South Florida Water Management District rationed water in Palm Beach County and around Lake Okeechobee in 1989, cutting the allotment for area farmers in half (Borenstein, 1989).

The potential impact of soil subsidence was ranked last as an issue of concern' for sod producers. Among others, two important factors that deplete soil reserves are biological and mechanical subsidence. Biological subsidence of organic soils is exacerbated in Florida by drainage for crop production, thereby initiating aerobic activity. A "mechanical" subsidence also takes place, primarily in the harvesting process when a layer of soil is removed with the root system of the grass. Over the years, the combined effects of biological and mechanical subsidence have depleted soil reserves in many parts of Florida. For instance, between 1924 and 1980, the reserves (relative depth of soils over limestone rock) at the Everglades Research Station were reduced by 66\% (Lucas, 1982; Snyder et al., 1978).

In turfgrass production, organic soils are subjected to both types of subsidence, whereas mineral soils, lacking substantial organic matter, are affected primarily by soil removal. In light of this, a logical hypothesis was that farmers whose fields were located on organic soils were more concerned about the issue of soil subsidence than those with land consisting of mineral soils. However, this was not found to be the case. When the data were analyzed by soil type (mineral vs. organic), both groups of producers were only moderately concerned about the subsidence issue. This result is partly explained by the statistical method used. Since these were frequency data and analyzed accordingly, the larger numerical group (mineral) dominated the outcome. Although operations on organic soils accounted for roughly 55\% of total production, a nonweighted analysis was used to present the industry's view of these issues, rather than the view of any particular group. Another factor is that some mineralbased operations were also faced with limited soil reserves. Both groups have individuals confronted with critical soil subsidence problems.

For most producers, subsidence is not an immediate threat. Assuming current practices continue, it will become important perhaps in 20,30 , or even 50 years from now. Some growers also rent land as a supplement to their owned acres. One would anticipate concern about subsidence to be inversely related to the amount of land rented. A higher ratio of rented to owned land implies a greater indifference for soil subsidence. However, it is arguable that certain cultural practices, such as improved harvesting methods, laser-planing to smooth fields, better establishment methods, and the use of machines that minimize unnecessary soil removal, indicate concern for subsidence. Substantial grower interest in improved production efficiencies (Fig. 1) may support this assertion.

Sod producers, as well as farmers in all sectors of agriculture, are increasingly challenged by society's growing concern over environmental issues. Agricultural enterprises are often perceived as a cause of, or a contributor to, declining environmental quality. As an individual commodity group, the turfgrass industry has been further challenged by claims that turfgrass areas should be limited or used in practical areas only, asserting that turf is a waste of natural resources, such as scarce water supplies (Donselman and Broschat, 1987). Therefore, the dilemma facing most agricultural commodity groups is how to remain economically viable and, at the same time, adopt practices that are acceptable to an increasingly strident and environmentally sensitive society.

Results from this study indicate that sod growers place greater emphasis on activities that improve their short-term economic position at the expense of addressing longerterm issues, such as government regulatory actions or the effects of diminishing soil reserves. Yet these issues must be dealt with eventually. A decision to delay action until the last possible moment is both a risky and, in all likelihood, a very costly strategy. Finally, it is important to emphasize that all segments of the turfgrass industry, not just sod producers, will be affected by these ongoing developments. As users of the same product, or as suppliers of inputs for that product, the welfare of the allied sectors will move in tandem with that of sod producers. Therefore, addressing these problems effectively will require that: first, the effort be industry-wide and second, it be initiated today to mitigate or avoid economic adversity tomorrow.

\section{Literature Cited}

Borenstein, S. 1989. Broward, Dade face early water cutbacks. Sun-Sentinel, Broward County, Fla., 6 Oct. p. 1.

Cisar, J. L., J.J. Haydu, S.D. Verkade, and K.E. Williams. 1988. The 1987 Florida sod production survey. Proc. Fla. State Hort. Soc. $101: 129$ 131.

Donselman, H. and T.K. Broschat. 1987. Xeriscape plant guide. South Florida Water Management District, West Palm Beach.

Florida Department of Agriculture and Consumer Services. 1976. Florida turfgrass survey, 1974. Crop Livestock Rpt. Serv., Florida Dept. Agr. Consumer Serv., Tallahassee.

Florida Department of Agriculture and Consumer Services. Jan. 1981. Rules of the division of plant industry. Div. of Plant Ind., Florida Dept. Agr. Consumer Serv., Tallahassee. p. 27.

Lucas, R.E. 1982. Organic soils (Histosols): Formation, distribution, physical and chemical properties and management for crop produc- 
tion. Res. Rpt. 435. Farm Science, Michigan State Univ., East Lansing.

Smith, C.N. and R.H. Brewster. 1968. An economic study of the Florida cut sod industry. Econ. Mimeo Rpt. EC 69-3, Dept. of Agricul- tural Economics, Agr. Expt. Sta., Univ. of Florida, Gainesville.

Snyder, G. H., H.W. Burdine, J.R. Crockett, G.J. Gasho, D.S. Harrison, G. Kidder, J.W. Mishoe, D.L. Myhre, F.M. Pate, and S.F. Smith. 1978.
Water table management for organic soil conservation and crop production in the Florida Everglades. Univ. of Florida, Agr. Expt. Sta. Bul. 801. 